\title{
An evaluation of community pharmacy-based services for type 2 diabetes in an Indonesian setting: patient survey
}

Yosi Wibowo, Richard Parsons, Bruce Sunderland, Jeffery Hughes

Background: Diabetes is an emerging chronic disease in developing countries. Its management in developing countries is mainly hospital/clinic based. The increasing diabetes burden in developing countries provides opportunities for community pharmacists to deliver a range of services. Since the management of diabetes requires the patient's own involvement, it is important to gain their views in order to develop pharmacy-based diabetes services. Studies on diabetes patients' views have been limited to developed countries. Objectives: To investigate, within a developing country setting (Indonesia), current use of pharmacy services by type 2 diabetes patients; and to evaluate their views regarding community pharmacists' roles, and the characteristics that influence their views. Methods: A questionnaire survey was conducted within 10 purposefully selected community pharmacies in Surabaya, Indonesia. Each pharmacy recruited approximately 20 patients seeking antidiabetic medications. Usage of pharmacy services was identified using binary responses ('yes'/'no') and views on pharmacists' roles were rated using Likert scales; an open-ended question was used to identify patient perceived priority roles. Logistic regression models were used to determine characteristics associated with patients' views. Results: A total of 196 pharmacy patients with type 2 diabetes responded (58.3\% response rate). Most patients used community pharmacies for dispensing (100\%) and education on how to use medications (79.6\%). There were mixed views towards pharmacists providing services beyond dispensing. The highest priorities identified were from the 'patient education' domain: education on medications [i.e. directions for use $(64.5 \%)$, storage $(26.6 \%)$, common/important adverse effects $(25.5 \%)$ ]; and the 'monitoring' domain: monitoring medication compliance (37.3\%). Patients with higher incomes or who were working were less supportive of these expanded services; whereas patients who previously used a service, those with risk factors for complications or having poor/unknown glycaemic control were more supportive. Conclusions: Community pharmacies in Surabaya, Indonesia in this study were mainly utilised for dispensing. However, many type 2 diabetes patients using these pharmacies report limited monitoring of blood glucose levels and poor glycaemic control, which indicates an opportunity for greater pharmacist involvement. Yet for this to occur, patients' limited expectations of 
pharmacists roles will need to be broadened. Characteristics influencing these views should inform the development of pharmacy-based diabetes services in the environment of the burgeoning burden of diabetes. 


\section{Title}

2 An evaluation of community pharmacy-based services for type 2 diabetes in an Indonesian

3 setting: patient survey

4

5

\section{Abstract}

7 Background: Diabetes is an emerging chronic disease in developing countries. Its management

8 in developing countries is mainly hospital/clinic based. The increasing diabetes burden in

9 developing countries provides opportunities for community pharmacists to deliver a range of services. Since the management of diabetes requires the patient's own involvement, it is important to gain their views in order to develop pharmacy-based diabetes services. Studies on diabetes patients' views have been limited to developed countries.

Objectives: To investigate, within a developing country setting (Indonesia), current use of pharmacy services by type 2 diabetes patients; and to evaluate their views regarding community pharmacists' roles, and the characteristics that influence their views.

Methods: A questionnaire survey was conducted within 10 purposefully selected community pharmacies in Surabaya, Indonesia. Each pharmacy recruited approximately 20 patients seeking antidiabetic medications. Usage of pharmacy services was identified using binary responses ('yes'/'no') and views on pharmacists' roles were rated using Likert scales; an open-ended question was used to identify patient perceived priority roles. Logistic regression models were used to determine characteristics associated with patients' views.

Results: A total of 196 pharmacy patients with type 2 diabetes responded (58.3\% response rate). Most patients used community pharmacies for dispensing (100\%) and education on how to use 
24 medications (79.6\%). There were mixed views towards pharmacists providing services beyond

25 dispensing. The highest priorities identified were from the 'patient education' domain: education

26 on medications [i.e. directions for use (64.5\%), storage (26.6\%), common/important adverse

27 effects (25.5\%)]; and the 'monitoring' domain: monitoring medication compliance (37.3\%).

28 Patients with higher incomes or who were working were less supportive of these expanded

29 services; whereas patients who previously used a service, those with risk factors for

30 complications or having poor/unknown glycaemic control were more supportive.

31 Conclusions: Community pharmacies in Surabaya, Indonesia in this study were mainly utilised

32 for dispensing. However, many type 2 diabetes patients using these pharmacies report limited

33 monitoring of blood glucose levels and poor glycaemic control, which indicates an opportunity

34 for greater pharmacist involvement. Yet for this to occur, patients' limited expectations of

35 pharmacists roles will need to be broadened. Characteristics influencing these views should

36 inform the development of pharmacy-based diabetes services in the environment of the

37 burgeoning burden of diabetes.

40 Authors

41 Yosi Wibowo ${ }^{1,2}$

42 Richard Parsons ${ }^{1}$

43 Bruce Sunderland ${ }^{1}$

44 Jeffery Hughes ${ }^{1}$ 
1. School of Pharmacy, Faculty of Health Sciences, Curtin University, GPO Box U1987, Perth, Western Australia 6845, Australia

2. Centre for Medicines Information and Pharmaceutical Care (CMIPC), Faculty of Pharmacy, University of Surabaya, Jl. Raya Kalirungkut, Surabaya, East Java 60293, Indonesia

51 Corresponding author:

52 Yosi Wibowo

53 Centre for Medicines Information and Pharmaceutical Care, Faculty of Pharmacy, University of

54 Surabaya, J1. Raya Kalirungkut, Surabaya, East Java 60293, Indonesia

55 Phone: +62312981170

56 Email: yosi.wibowo@postgrad.curtin.edu.au

\section{Introduction}

Indonesia is a major developing country with a population of 237.6 million [1], and is among the top 10 countries in the world according to the number of people with diabetes [2]. In 2013, it was estimated that 8.5 million people in Indonesia were living with diabetes, and this number is expected to increase to 14.1 million by 2035 [2]. Diabetes in Indonesia is currently managed in hospital outpatient or clinic settings $[3,4]$. An increased number of people with diabetes will require more community-based care, providing an opportunity for community pharmacists to deliver a range of diabetes services. While the 2012 Indonesia Health Profile reported a total of 
68 have limited roles within Government insurance plans, providing services mainly to the private

69 sector [6].

70

71 The introduction of Standards for Pharmaceutical Care in Community Pharmacies in 2006 has

72

73

74

emphasised the need for community pharmacists to be involved in the care of patients with chronic diseases, including diabetes [7].The standards included a range of services, i.e. prescription medication service (i.e. prescription review, drug dispensing/supply, drug information and counselling, and monitoring), health promotion and education to promote selfcare, and home/residential care [7]. A previous study involving a survey of community pharmacists in Surabaya, Indonesia reported despite community pharmacists' expressed willingness to take up a broader role in diabetes care, the majority performed limited services beyond dispensing [8]. Studies in developed countries (such as the UK, the USA, Canada and European countries), however, reported that more than $50 \%$ of community pharmacies have provided extended services for diabetes patients, including: education related to medications, lifestyle education, supporting patients in performing self-monitoring of blood glucose (SMBG), and monitoring compliance with medications [9-16].

To increase the uptake of pharmacy-based services amongst diabetes patients in Indonesia, it is important to understand the perspectives of diabetes patients on pharmacy-based services that would assist with their care. This is especially so since diabetes is a chronic disease that requires daily care in the hands of patients [17]. Several studies have been conducted to investigate diabetes patient views regarding aspects of community pharmacists' roles, however, these have thus far been limited to developed countries, such as the UK and the USA [17-21]. Two previous 
91 small studies conducted in community pharmacies in Indonesia, although not specific to diabetes

92 patients, have found that general patients had positive perceptions of pharmacy services, 93 providing facilitation for pharmacists to develop their professional roles [22,23]. This present 94 study aimed to investigate, within an Indonesian setting, the current use of community pharmacy

95 services by patients with type 2 diabetes; and to evaluate their views on the potential roles of 96 community pharmacists, and the characteristics that influence their views. The results of the 97 study should inform the Government, professional bodies, and practitioners on the development 98 of pharmacy-based diabetes services in a developing country setting (Indonesia).

\section{Methods}

102 This study was approved by the Human Research Ethics Committee of Curtin University (PH09-11) and Ikatan Apoteker Indonesia - IAI (Indonesian Pharmacists Association) (001/SK/BPD-IAI/SURABAYA/2010).

\section{Setting and sample recruitment}

107 The aims of the study included the estimation of the prevalence of service usage and patient views. A sample size of 200 was defined which if broadly representative of the population of pharmacy patients with type 2 diabetes in Surabaya, the $95 \%$ confidence intervals for the true prevalence estimates would be within $7 \%$ of the figures obtained from the sample (based on a

111 prevalence estimate of 50\%). For the analysis of characteristics associated with respondents' 112 views, a sample of 200 would be expected to be adequate to identify any independent variables 113 exhibiting a moderate to small effect size (with power $=80 \%, \alpha=0.05$ ) [24]. 
115 A previous pharmacist survey had been conducted on a random sample of 400 community 116 pharmacies in Surabaya (60\% response rate), providing data on the characteristics of the 117 community pharmacies and diabetes services provided (reported elsewhere) [8]. Based on the 118 pharmacy characteristics data, 10 community pharmacies were purposefully selected as sampling

119 sites in this study, aiming to include different geographical areas and socio-economic levels in 120 Surabaya. Surabaya consists of 31 sub-districts which can be categorised into five geographical 121 areas, namely: centre, west, east, north and south; and four socio-economic levels, from high 122 (labelled ' 1 ') to low (labelled '4') [25]. Each pharmacy was responsible for recruiting 123 approximately 20 patients. Patients eligible for the survey were those aged over 18 years, with a 124 diagnosis of type 2 diabetes for which they were receiving oral antidiabetic medications. Patients 125 were recruited as they were seeking oral antidiabetic medications at these pharmacies, and their 126 written consent was obtained.

\section{Data Collection}

129 Questionnaire development. The survey questionnaire consisted of four sections: (A) patient 130 demographics, (B) services for type 2 diabetes patients - use of services and views on 131 pharmacists' roles, (C) diabetes profile, and (D) monitoring profile. The questionnaire cover 132 page contained information about the study and a consent form. Section B of the questionnaire contained a list of services for type 2 diabetes patients that was drafted based on a generic model generated from the literature [26-30]. A binary choice question was used to capture patient usage of each service ('yes'/'no'), and a 6-point Likert scale was used to reflect patient views on

136 pharmacists' roles $(1=$ definitely no, 6=definitely yes). This was followed by an open-ended 
137 question to explore patient priorities regarding their views of pharmacist roles: 'In your opinion,

138 what are the five most important services that should be provided at pharmacies to assist you

139 with your diabetes?' The questionnaire was face and content validated by a panel of seven

140 academics, two board members of the IAI, two Indonesian community pharmacists and two

141 diabetes patients. Their feedback, where appropriate, was incorporated into the questionnaire.

143 The questionnaire (English version) then went through a translationprocess to an Indonesian

144 version: (i) forward translation to Bahasa Indonesia by one of the investigators whose first

145 language is Bahasa Indonesia; (ii) back-translation to English by an independent English first-

146 language translator; and (iii) the back-translation was compared to the original version by two of

147 the investigators whose first language was English. The forward-translation questionnaire was

148 piloted by 10 type 2 diabetes patients. This resulted in minor changes to the final questionnaire.

149 To assess reliability, the questionnaire was distributed on two occasions separated by a two-week

150 interval. Responses to the Likert scales were grouped (ratings of 1 to 4, and ratings of 5 to 6) to

151 ensure that Kappa was able to be calculated; the resulting Kappa scores for diabetes services

152 (Section B) ranged from 0.412 to 1.000 , which were classified as 'acceptable' to 'excellent'

153 levels of test-retest reliability[31].

155 Questionnaire administration. Owners of the 10 selected pharmacies were approached. In the 156 case of refusal, that pharmacy was replaced with another pharmacy in the same geographical area and socio-economic level (Table 1). At each pharmacy, 40 questionnaires were issued, and the pharmacist and/or pharmacy staff member was briefed about the study and how to complete the questionnaire. The pharmacist and/or the pharmacy staff member was asked to explain about 
160 the study to the eligible patients and to invite them to participate; each pharmacy aimed to recruit

161 approximately 20 patients. Once completed, the questionnaire was placed in a sealed envelope

162 by the respondent and submitted to the pharmacist/pharmacy staff. The completed questionnaires

163 as well as the remaining unused questionnaires were then handed to the investigators by the 164 agreed deadline.

\section{Data Analysis}

167 Descriptive statistics were used to summarise the patient characteristics: demographics (Section

168 A), diabetes profile (Section C), and monitoring profile (Section D). SPSS version 19.0 was used 169 to perform the analysis.

170

171 In relation to diabetes services (Section B), frequencies were calculated for binary responses

172 ('yes'/'no') related to the patient usage of services and for responses from Likert scales related to 173 the extent of patient agreement regarding pharmacists' roles. Moreover, content analysis was 174 used for responses from the open-ended question to explore patient views on the five priority 175 services that should be provided at the pharmacies. An initial coding frame structure was established from the generic model generated from the literature. The responses were coded (if new codes emerged, they were added to the thematic codes in the coding frame), and 178 frequencies were calculated for each code [32].

It was of particular interest to identify characteristics associated with the views of patients related to pharmacy-based diabetes services. For this reason, the responses regarding patients' views for each type of service were classified into binary variables, to indicate 'strong agreement' (Likert 
183 scale ratings of 5 to 6) versus 'ambivalence or disagreement' (Likert scale ratings of 1 to 4 ) that a

184 service should be provided by the pharmacy. These binary variables were used as dependent

185 variables in logistic regression models to identify patient characteristics associated with the

186 strong support for each role. Some roles were considered to be different aspects of an

187 overarching role. For example, the roles to provide information on: the taking of medications,

188 use of insulin devices, storage of medications, precautions, and adverse effects were all

189 components of 'medication education'. In order to analyse characteristics associated with strong

190 support for an overarching or 'composite' role, the arithmetic average of the Likert responses for

191 the component roles was calculated and then converted to a binary variable in a manner similar

192 to that used for the individual roles (scores of 5 or more were taken to indicate strong support,

193 otherwise ambivalence or low support). Taking the simple average of the component roles

194 implicitly gives equal weight to each of the roles within a composite. It would have been

195 preferable to use Factor Analysis to identify if some of the component roles were more important

196 than others, but the sample size was considered too small for this refinement. It is generally

197 recommended that sample sizes of 300 or more should be used to obtain stable factor loadings

198 [24]. Patient characteristics included as independent variables were gender, age, education,

199 employment, income, health insurance cover, diabetes organisation membership, duration of

200 diabetes (time since diagnosis), risk factors for complications, complications and diabetes

201 (glycaemic) control. The models also included an independent variable indicating patients'

202 previous use of the service (binary responses: 'yes'/'no'). For dependent variables which were

203 'composite' (for example 'medication education'), the binary responses indicating previous use

204 of each component service were treated as numeric (zero for 'No', one for 'Yes'), and their mean

205 was calculated and used in the model as an independent variable to show the degree of previous 
206 use of the composite service. A mean value close to 1 indicated that most components of 207 thecomposite role had been used, while a lower value indicated less use. A backward elimination 208 strategy was used to identify all the variables which significantly contributed to each model. 209 Through this approach all independent variables were included initially, and then the least 210 significant variable was dropped (one at a time) until the p-value associated with each of the 211 variables remaining in the model was less than 0.05 .

212

213

\section{Results}

216 Sample recruitment

217 This study included 10 community pharmacies as sampling points after approaching 11 218 community pharmacies in Surabaya. One pharmacy refused, as the employee pharmacist was 219 planning to resign and they were in the process of recruiting a new one. From the final 10 220 pharmacies, a total of 336 questionnaires were distributed and 204 were returned; however, eight 221 patients reported the use of insulin at the beginning of their therapies and were deemed to have 222 type 1 diabetes, leaving a sample size of 196 (a response rate of 58.3\%) (Table 1). 
[Insert Table 1 here]

225

226 Characteristics of pharmacy patients with type 2 diabetes

227 The demographic information of participating patients (Section A) is summarised in Table 2. Approximately $60 \%$ of respondents were female and half of respondents were aged 60 years or older. Approximately half of the respondents did not have health insurance plans.

The diabetes data reported by participating patients (Section C) are shown in Table 3. The median duration of diabetes (time since diagnosis) was seven years. More than $80 \%$ of respondents reported that their treatment regimen included oral antidiabetic medications and diet modifications. It is important to note that this variable did not measure whether the doctor made the medication/diet/exercise recommendations, but rather whether the patient remembered and/or reported it. Almost $60 \%$ of the respondents reported having at least one diabetes-related complication, and most of the patients reported having at least one risk factor for complications.

241 [insert Table 3 here]

Table 4 shows the monitoring profile reported by participating patients (Section D). HbAlc refers to glycosylated hemoglobin, which identifies average plasma glucose concentration over the previous three months. To provide insight to patients' diabetes (glycaemic) control, variables related to the symptoms of hypo/hyperglycaemia and HbAlc values were combined to indicate: 
247 fair-good control (i.e. no symptoms and $\mathrm{HbA1c} \leq 8.0 \%$ ); poor control (i.e. presence of symptoms

248 and/or HbAlc >8.0\%); and unknown (i.e. symptoms 'none/don't know' and/or HbA1c values

249 'none/don't know'). Using this derived variable, most respondents were perceived to have either

250 poor diabetes control (45.9\%) or unknown diabetes control $(42.3 \%)$.

252 [insert Table 4 here]

253

254

\section{Patients' use of pharmacy services and their views on pharmacist roles}

Responses describing patient usage of pharmacy services are summarised in Table 5. In addition

to the traditional role of dispensing ('treatment administration'), the most frequent services received were 'patient education' about medications, particularly directions for use (79.6\%) and special precautions to follow (71.9\%).

Table 5 also shows responses regarding pharmacists' roles. All patients agreed with pharmacists' roles in dispensing. Beyond dispensing, more than $70 \%$ of respondents expected pharmacists to provide 'patient education' about medications. About half of respondents supported other activities related to 'patient education' and 'monitoring'. There were large gaps between patient usage and expectation regards education on: medication storage and adverse effects, SMBG, prevention of complications, need for regular monitoring, and foot care. In addition, patients expected pharmacists to provide more monitoring services than those currently provided. 
270 In terms of the priority roles of pharmacists, patients' responses can be seen in Table 6. The top

271 five services perceived by patients as priorities (in addition to pharmacists' traditional roles of

272 dispensing being already provided) were from the 'patient education' domain - education related

273 to medications [i.e. directions for use (64.5\%), common/important adverse effects $(25.5 \%)$,

274 storage requirements $(26.6 \%)]$ and the 'monitoring' domain - monitoring compliance with

275 medications (37.3\%). No new services were raised, beyond those already listed in the

276 questionnaire, from this open-ended question, suggesting that from the respondents' perspective

277 the range of services that should be provided by community pharmacies described in Table 5 was

278 complete.

279

$280 \quad$ [insert Table 6 here]

281

\section{Characteristics associated with patients' views on pharmacist roles}

283 Logistic regression models were used to identify patient characteristics which were associated with patients' views on pharmacists' roles. The odds ratios of significant characteristics are summarised in Table 7.

286

287 [insert Table 7 here]

288

Patient experience (previous use) with a service was strongly associated with their views that the service should be provided by pharmacists [Odds Ratios (ORs) 4.4 to 11.3]. Patients with poor/unknown glycaemic control or those who had risk factors for complications were more supportive of pharmacists providing some monitoring services (ORs 2.3 to 10.2). On the other 
293 hand, patients with higher incomes or those who were working were less supportive towards

294 pharmacists providing some education and monitoring services (ORs 0.3).

295

296

\section{Discussion}

298 This study has foundmost type 2 diabetes patients recruited had complications and/or risk factors 299 for complications (80.1\% and 58.7\%, respectively), and/or had poor/unknown glycaemic control 300 (45.9\% and $42.3 \%$, respectively). It is evident that in the current hospital outpatient/clinic treatment model many patients were poorly monitored. This is consistent with a population study

302 of type 2 diabetes patients in Indonesia which reported that $67.9 \%$ of type 2 diabetes patients had 303 not achieved good glycaemic control (HbAlc $<7.0 \%)$, and approximately $60 \%$ of the patients had complications and/or risk factors for complications (i.e. dyslipidaemia and/or hypertension) 305 $[3]$.

Moreover, this study reported that follow-up care tended to be inadequate, with only about onethird of respondents reporting annual HbAlc monitoring and eye or foot examinations. Supporting this finding, the Patient and Health Provider Survey in Indonesia (2012) indicated that the majority of patients had not received foot or eye examinations within the past year, only

$31130 \%$ had had their HbA1c checked and many had expressed a wish to see health care providers 312 more often [33]. It was suggested that this poor quality of care and patient outcomes might relate 313 to the lack of awareness of, accessibility to and affordability of diabetes care for this patient 314 group [33]. Together with the findings of this study it provides a basis for community 315 pharmacists to provide a range of services. 
317 Patients' use of pharmacy services and their views on pharmacist roles

318 This study indicated little involvement of Indonesian community pharmacies in the care of

319 patients with type 2 diabetes. Respondents mostly utilised pharmacists for their supply role

320 (dispensing). A previous Indonesian studyhas confirmed the limited services provided to general

321 pharmacy patients [22].

322

323

Amongst non-supply roles, many respondents chose roles closely related to dispensing as the priority roles of pharmacists, i.e. education related to medications, and monitoring compliance with medications. Similar findings were evident from some international studies involved diabetes patients [17-21].Two qualitative studies indicated that patients identified the primary expertise of the community pharmacist as medicines supply, and there were mixed perceptions of community pharmacists' roles extending to advising on prescription medicines, providing disease-related/health advice or providing monitoring services (using clinical testing devices)[21, 34].

It is interesting that the responses to the open-ended question that patients perceived that services related to dispensing and patient education were those that should be provided to type 2 diabetes patients from community pharmacies (Table 6). All of those they considered should be provided had been included in the options that could be provided (Table 5). This also indicated that patients did not have additional requirements for services not identified initially for this study. 


\section{Characteristics associated with patients' views on pharmacist roles}

339 The logistic regression models consistently found that a patient's support for a service was

340 influenced by their experience (previous use) of the service (Odds Ratios, ORs $\geq 4.4$ ). Supporting

341 this finding, studies worldwide have shown that type 2 diabetes patients have increased

342 perceptions of pharmacists' ability to assist them after receiving pharmacy-based services [35-

343 39]. It should be emphasised that most patients in this study (at that time) received limited

344 services from community pharmacies, thus they might not be aware of what pharmacists should 345 and could do.

347 The implementation of Jaminan Kesehatan Nasional - JKN (National Health Coverage) in 2014 348 provides the best opportunity to optimise the use of Indonesian community pharmacies. It is 349 important for the Government and IAI to establish an agreement on the basic services that should 350 be available in community pharmacies. While the current payment under the scheme includes a 351 very low prescription fee [40], the IAI should negotiate adequate remuneration for pharmacists to 352 provide the services, thus enabling community pharmacies to remain viable.

354 In addition to patients' past experiences, patients who were working and/or had higher incomes were generally less supportive of some of the proposededucation or monitoring services (ORs $356 \leq 0.5$ ). This might be because these groups of patients were likely to be younger (mean age 63.7 years for non-workers versus 54.0 years for workers, $\mathrm{p}<0.0001$; and mean age 60.4 years for

358 income $\leq \operatorname{Rp} 5$ million versus 58.6 years for income $>\operatorname{Rp} 5$ million, $\mathrm{p}=0.358$ ). Two previous 359 studies have reported that older patients, or those living with diabetes for a long time, were more 
360 supportive of pharmacists' contributions [21,41]. It has been suggested that elderly people are

361 one of the groups whose need for additional advice on medications and other related services has

362 been demonstrated [42].

363

364 Notably, patients who had risk factors for complications and/or had poor/unknown glycaemic

365 control were much more supportive of pharmacists monitoring treatment outcomes or adverse

366 drug reactions (ORs $\geq 2.3$ ). Such patients might reflect those with lower health status,

367 representing a target group who might be more motivated and responsive to pharmacists'

368 involvement. It has been suggested that patients who benefit most from pharmacist-led

369 education/coaching and disease state management services include those with poor glycaemic

370 control and multiple comorbidities [43]. It is evident that overall treatment outcomes in this

371 patient cohort are concerning and expanding the community pharmacy role into patient

372 management needs to be investigated.

373

374 Limitations

375 The purposeful sampling method used in the study (20 patients from each of 10 pharmacies) was

376 considered the only feasible manner by which it could be conducted. The request for

377 approximately 20 patients was to ensure that each pharmacy included a range of patients in the

378 sample and in many cases this about half of their current type 2 diabetes patients. No full list

379 (sampling frame) of pharmacy patients with diabetes exists in Surabaya, so it was not possible to

380 obtain a truly random sample of patients with this condition. Thus, there is a possibility of non-

381 respondents not sharing the same practice and/or views of respondents, and some caution should

382 be exercised in generalising the findings. However, the pharmacies covered a wide range of 
383 settings (geographic and socioeconomic), so that no particular background group of patients

384 would be excluded; and achieved a sound response rate of approximately $60 \%$. The

385 characteristics of the respondents in this study were comparable to those of a population study

386 involving all type 2 diabetes patients visiting 18 medical centres across Indonesia between

387 November 2008 and February 2009 ( N=1785) with respect to age (60 years versus 59 years,

388 respectively), gender (female 59.2\% versus 55.2\%, respectively), and duration of diabetes (7

389 years versus 8 years, respectively) [3]. Hence, although the sample is not randomly selected and

390 the risk of response bias might limit the generalisation, the views of participants give some

391 insight into the diabetes services used or desired at community pharmacies in Surabaya.

393

Conclusions

394

Community pharmacies in Surabaya, Indonesia in this study are mainly utilised for their basic services of dispensing. Many type 2 diabetes patients in these pharmacies reported limited monitoring of blood glucose and poor glycaemic control; in addition, their follow-up care and health outcomes were generally poor. These findings indicate a need and opportunities for community pharmacists to provide a range of services for patients with diabetes. Hence, strategies should be developed to broaden current pharmacy patients' limited views of pharmacists' roles which are mainly perceived as extensions to the supply roles. It is evident that patients support the provision of services once they have been provided. Patient characteristics that influence these views provide a target group for implementation of a pharmacy-based diabetes service that should be evaluated. This can provide a partial solution in the environment of a burgeoning burden of diabetes in Indonesia. 


\section{Acknowledgements}

408 We thank all the participants who took part in the survey as well as Ikatan Apoteker Indonesia409 IAI (Indonesian Pharmacists Association) and staff from the Centre of Medicines Information 410 and Pharmaceutical Care (CMIPC), Pharmacy Faculty, University of Surabaya, for their 411 technical support in making this study possible. 


\section{References}

414 1. International Diabetes Federation (IDF). IDF Diabetes Atlas 6th edition [Internet]. Brussels: 415 IDF; 2013 [cited 2015May15]. Available from:

416 http://www.idf.org/sites/default/files/EN_6E_Atlas_Full_0.pdf. ISBN: 2930229853.

417 2. Fowler M. Microvascular and macrovascular complications of diabetes. Clin Diabetes. 2008; $418 \quad 26(2): 77-82$.

419 3. Soewondo P, Soegondo S, Suastika K, Pranoto A, Soeatmadji D, Tjokroprawiro A. The 420 DiabCare Asia 2008 study - outcomes on control and complications of type 2 diabetic 421 patients in Indonesia. Med J Indon. 2010; 19(4):235-244.

4. Soewondo P, Ferrario A, Tahapary D. Challenges in diabetes management in Indonesia: a literature review. Glob Health. 2013; 9(1):63.

5. Kementrian Kesehatan Republik Indonesia (KemenkesRI). Indonesia health profile 2012 [Internet]. Jakarta: KemenkesRI; 2013 [cited 2015 May15]. Available from: http://depkes.go.id/downloads/Profil\%20Kesehatan_2012\%20(4\%20Sept\%202013).pdf

6. Wang H, McEuen M, Mize L, Cisek C. Private sector in Indonesia: a desk review [Internet]. Bethesda: Health Systems 20/20 project Abt Associates Inc.; 2009 [cited 2015 May9]. Available from: http://www.healthsystems2020.org/content/resource/detail/2355/

7. Kementrian Kesehatan Republik Indonesia (KemenkesRI). Keputusan Menteri Kesehatan nomor 1027/MENKES/SK/IX/2004: standar layanan kefarmasian di apotek[Ministry of Health Decree number1027/MENKES/SK/IX/2004: standards for pharmaceutical care in community pharmacies]. Jakarta: KemenkesRI; 2006.

8. Wibowo Y, Parsons R, Hughes J, Sunderland B. An evaluation of community pharmacybased services for type 2 diabetes in an Indonesian setting: Pharmacist Survey. Int J Clin Pharm. Forthcoming 2015. DOI :10.1007/s11096-015-0135-y.

9. Simpson S, Haggarty S, Johnson J, Schindel T, Ross T, Lewanczuk R. Survey of pharmacist activities and attitudes in diabetes management. Can Pharm J. 2009; 142(3):127-134.

10. Douglas E, Power A, Hudson S. Pharmaceutical care of the patient with diabetes mellitus: pharmacsts' priorities for services and educational needs in Scotland. Int J Pharm Pract. 2007; $15(1): 47-52$. 
442 11. Abduelkarem A, Sackville M, Morgan R, Sackville M, Hildreth A. Views and practices of 443 community pharmacists regarding services for people with type 2 diabetes. Int J Pharm Pract $444 \quad 2003 ; 11(3): 161-168$.

445 12. Younis W, Campbell S, Slack M. Pharmacists' attitudes toward diabetes and their 446 involvement in diabetes education. Ann Pharmacother. 2001; 35(7):841-845.

447 13. Kjome R, Sandberg S, Granås A. Diabetes care in Norwegian pharmacies: a descriptive $448 \quad$ study. Pharm World Sci 2008; 30(2): 191-198.

449

450

451

452

453

454

455

456

457

458

459

460

461

462

463

464

465

466

467

468

469

470

14. Plake K, Chesnut R, Odorzynski M. Barriers to community pharmacists' provision of diabetes care services in Iowa. J Pharm Technol. 2007; 23(6):327-338.

15. Storimans J. Pharmaceutical care in diabetes: Quantifying and evaluating community pharmacy's support to patients performing blood glucose self-monitoring [dissertation]. Uthrecht, the Netherlands: Utrecht University; 2005.

16. Timmer J, de Smet P, Schuling J, Tromp T, de Jong-van den Berg L. Patient education to users of oral hypoglycaemic agents: the perspective of Dutch community pharmacists. Pharm World Sci. 1999; 21(5):200-204.

17. Abduelkarem A, Sackville M, Morgan R, Hildreth A. An assessment of the level of type 2 diabetes patients' satisfaction with community pharmacists' services. Pharm J. 2003; 270(7242):446-449.

18. Weitzman A, McDowell K, Elswick B, Blommel M. Patient perceptions of pharmacists' role in diabetes: results of an Operation Diabetes initiative. J Am Pharm Assoc. 2009; 49(6):716717.

19. Brown C, Green A. Expectations of patients with diabetes for pharmaceutical care services in community pharmacy settings. J Soc Admin Pharm. 2000; 17: 219-223.

20. Hermansen-Kobulnicky C, Worley M. Exploring the patient perspective regarding community pharmacists' educational roles in diabetes medication and blood glucose management. Int J Pharm Pract. 2008; 16(2):81-90.

21. Twigg M, Poland F, Bhattacharya D, Desborough J, Wright D. The current and future roles of community pharmacists: views and experiences of patients with type 2 diabetes. Res Soc Admin Pharm. 2013; 9(6):777-789. 
471

472

473

474

475

476

477

478

479

480

481

482

483

484

485

486

487

488

489

490

491

492

493

494

495

496

497

498

499

500

501

22. Handayani R, Raharni, Gitawati R. Persepsi konsumen apotek terhadap pelayanan apotek di tiga kota di Indonesia [pharmacy customers'perceptions regarding pharmacy services in the three cities in Indonesia]. Makara Kesehat. 2009; 13(1):22-26.

23. Abdullah N, Andrajati R, Supardi S. Pengetahuan, sikap dan kebutuhan pengunjung apotek terhadap informasi obat di kota Depok [Pharmacy customers' knowledge, attitude and needs of drug information in the city of Depok]. Bul Penelit Sist Kesehat. 2010; 13(4):344-352.

24. Tabachnick B, LS Fidell L. Using Multivariate Statistics. $5^{\text {th }}$ ed. Boston: Pearson Education Inc.; 2007.

25. Nugroho M. Analisis pengelompokan dan pemetaan kecamatan sebagai dasar program untuk mengatasi masalah-masalah sosial-ekonomi di Kota Surabaya[Analysis of distric mapping systemto manage socio-economic issues in Surabaya] [dissertation]. Surabaya: Institut Sepuluh Nopember; 2010.

26. Perkumpulan Endokrinologi Indonesia (PERKENI). Konsensus pengendalian dan pencegahan diabetes mellitus tipe 2 di Indonesia 2011 [The 2011 consensus for the management and prevention of type 2 diabetes mellitus in Indonesia] [Internet]. Jakarta: PERKENI; 2011 [cited 2015May 17]. Available from: http://www.perkeni.org/

27. Power A, Douglas E, Mc Gregor A, Hudson S. Professional development of pharmaceutical care in type 2 diabetes mellitus: a multidisciplinary conceptual model. Int J Pharm Pract. 2006; 14(4):289-299.

28. Diabetes Australia. Diabetes management in general practice: guidelines for type 2 diabetes 2012/13. Canberra: Diabetes Australia Limited; 2012.ISBN: 9781875690190.

29. American Diabetes Association. Standards of medical care in diabetes - 2013. Diabetes Care. 2013; 36 Suppl 1:S11-66.

30. Department of Health Western Australia. Diabetes model of care [Internet]. Perth: Department of Health Western Australia; 2008 [cited 2012 June 20]. Available from: http://www.healthnetworks.health.wa.gov.au/modelsofcare/docs/Diabetes_Model_of_Care.p df

31. Landis J, Koch G. The measurement of observer agreement for categorical data. Biometrics. 1977; 33(1):159-174.

32. Rose S, Spinks N, Canhoto AI. management research: applying the principles. London \& New York: Routledge; 2015 
502 33. Novo Nordisk. Where economics and health meet: changing diabetes in Indonesia: the

503

504

505

506

507

508

509

510

511

512

513

514

515

516

517

518

519

520

521

522

523

524

525

526

527

528

529

530

531 blueprint for change programme [Internet]. 2013 [cited 2015 May 11]. Available from:http://www.novonordisk.com/images/Sustainability/PDFs/Blueprint-for-changeIndonesia--52383_Korr19.pdf.

34. Gidman W, Cowley J. A qualitative exploration of opinions on the community pharmacists' role amongst the general public in Scotland. Int J Pharm Pract. 2013; 21(5):288-296.

35. Fera T, Bluml B, Ellis W, Schaller C, Garrett D. The diabetes ten city challenge: interim clinical and humanistic outcomes of a multisite community pharmacy diabetes care program. J Am Pharm Assoc. 2008; 48(2):181-190.

36. Garrett D, Martin L. The Ashville project: participants' perceptions of factors contributing to the success of a patient self management diabetes program. J Am Pharm Assoc. 2003; 43(2):185-190.

37. Hughes J. Final report: customised education programs for patients with diabetes mellitus use of structured questionnaires and education modules (DMEP Study). Perth: CurtinUniversityof Technology; 2006.

38. Abduelkarem A, Sackville M. Changes of some health indicators in patients with type 2 diabetes: a prospective study in three community pharmacies in Sharjah, United Arab Emirates. Libyan J Med. 2009; 4(1):31-36.

39. Hales J, Alderdice A, Staniford T, Manser J. Evaluation of the diabetes pilot program. Adelaide: Australian Government Department of Health and Ageing; 2010.

40. Kementrian Kesehatan Republik Indonesia (KemenkesRI). Surat Edaran nomor HK/MENKES/31/2014: pelaksanaan standar tarif pelayanan kesehatan pada fasilitas kesehatan tingkat pertama dan fasilitas kesehatan tingkat lanjutan dalam penyelenggaraan program jaminan kesehatan [Operational standards for remuneration of primary and secondary/tertiary health care services in the health insurance program]. Jakarta; KemenkesRI; 2014.

41. Ibrahim I, Al Tukmagi H, Wayyes A. Attitudes of Iraqi society towards the role of community pharmacists. Innov Pharm. 2013; 4(2):1-10.

42. Cartwright A, Smith C. Elderly people, their medicinse, and their doctors. London: Routledge; 1988.ISBN:9780415006842 
532 43. Sisson E, Kuhn C. Pharmacist roles in the management of patients with type 2 diabetes. J Am 533 Pharm Assoc. 2009; 49 Suppl 1:S41-45.

534

535

536

537 
Table $\mathbf{1}$ (on next page)

patient recruitment 
1 Table 1 Patient recruitment data from 10 community pharmacies

2

\begin{tabular}{|l|l|c|c|c|c|}
\hline \multicolumn{1}{|c|}{$\begin{array}{c}\text { Pharmacy } \\
\text { code }\end{array}$} & $\begin{array}{c}\text { Geographical } \\
\text { area }\end{array}$ & $\begin{array}{c}\text { Socio- } \\
\text { economic } \\
\text { level }\end{array}$ & $\begin{array}{c}\text { Average number } \\
\text { of } \\
\text { diabetes patients } \\
\text { per month }\end{array}$ & $\begin{array}{c}\text { Number of } \\
\text { questionnaires } \\
\text { distributed }\end{array}$ & $\begin{array}{c}\text { Number of } \\
\text { useablequestionnai } \\
\text { res returned }\end{array}$ \\
\hline Pharmacy 1 & East Surabaya & 2 & 150 & 40 & 21 \\
\hline Pharmacy 2 & $\begin{array}{l}\text { Central } \\
\text { Surabaya }\end{array}$ & 1 & 200 & 28 & 18 \\
\hline Pharmacy 3 & East Surabaya & 3 & 70 & 35 & 20 \\
\hline Pharmacy 4 & West Surabaya & 4 & 100 & 32 & 19 \\
\hline Pharmacy 5 & South Surabaya & 3 & 140 & 37 & 20 \\
\hline Pharmacy 6 & Central & 2 & 100 & 30 & 20 \\
\hline Pharmacy 7 & South Surabaya & 4 & 100 & 36 & 19 \\
\hline Pharmacy 8 & North Surabaya & 1 & 240 & 31 & 20 \\
\hline Pharmacy 9 & West Surabaya & 3 & 120 & 40 & 19 \\
\hline Pharmacy 10 & North Surabaya & 2 & 100 & 27 & $\mathbf{1 9 6}$ \\
\hline Total & & & & $\mathbf{3 3 6}$ & \\
\hline
\end{tabular}

3 
Table 2 (on next page)

demographic data 
1 Table 2 Demographic data of patient respondents $(\mathrm{N}=196)$

2

\begin{tabular}{|c|c|}
\hline Patient demographics & Frequency $(\%)$ \\
\hline \multicolumn{2}{|l|}{ Gender } \\
\hline Male & $80(40.8)$ \\
\hline Female & $116(59.2)$ \\
\hline Age, years - median (range) & $60.0(32-86)$ \\
\hline \multicolumn{2}{|l|}{ Ethnicity } \\
\hline Asian & $196(100.0)$ \\
\hline Others & $0(0.0)$ \\
\hline \multicolumn{2}{|l|}{ Highest Education } \\
\hline No schooling & $6(3.1)$ \\
\hline Primary school & $23(11.7)$ \\
\hline Junior high school & $41(20.9)$ \\
\hline Senior high school & $71(36.2)$ \\
\hline Diploma & $18(9.2)$ \\
\hline Bachelor degree & $25(12.8)$ \\
\hline Postgraduate degree & $12(6.1)$ \\
\hline \multicolumn{2}{|l|}{ Employment status } \\
\hline $\begin{array}{l}\text { Working full-time } \\
(\geq 40 \text { hours/week) }\end{array}$ & $53(27.0)$ \\
\hline $\begin{array}{l}\text { Working part-time } \\
\text { (<40 hours/week) }\end{array}$ & $20(10.2)$ \\
\hline Not working & $123(62.8)$ \\
\hline \multicolumn{2}{|c|}{ Total household income (from all sources) per month ${ }^{\mathrm{a}}$} \\
\hline$\leq \mathrm{Rp} 2$ million & $103(52.6)$ \\
\hline$>$ Rp 2 million -5 million & $54(27.6)$ \\
\hline$>$ Rp 5 million -10 million & $25(12.8)$ \\
\hline$>$ Rp 10 million & $12(6.1)$ \\
\hline \multicolumn{2}{|l|}{ Health insurance } \\
\hline Self-sponsored insurance & $31(15.8)$ \\
\hline Employer-sponsored insurance & $56(28.6)$ \\
\hline Insurance scheme for the poor/near poor & $9(4.6)$ \\
\hline No insurance & $100(51.0)$ \\
\hline \multicolumn{2}{|l|}{ Member of a diabetes organisation } \\
\hline Yes & $74(37.8)$ \\
\hline No & $122(62.2)$ \\
\hline
\end{tabular}


3 Abbreviations:Rp, Indonesian rupiah

4 a2 missing responses

5 
Table 3 (on next page)

diabetes and health profile 
1 Table 3 Self-reported diabetes and health profile of patient respondents $(\mathrm{N}=196)$

2

\begin{tabular}{|c|c|}
\hline Patient diabetes profile & Frequency (\%) of 'yes' \\
\hline Duration of diabetes, years - median (range) ${ }^{\mathrm{a}}$ & $7(1-42)$ \\
\hline \multicolumn{2}{|l|}{ Current diabetes treatment } \\
\hline Modifying diet & $173(88.3)$ \\
\hline Exercise programme & $123(62.8)$ \\
\hline Oral Antidiabetic Medication & $189(96.4)$ \\
\hline Insulin & $44(22.4)$ \\
\hline Risk factors $\mathbf{c}$ & $157(80.1)$ \\
\hline $\mathrm{BMI} \geq 25 \mathrm{~kg} / \mathrm{m}^{2 \mathrm{~b}}$ & $88(44.9)$ \\
\hline (History of) smoking & $41(20.9)$ \\
\hline High cholesterol $^{\mathrm{d}}$ & $77(39.5)$ \\
\hline High blood pressure ${ }^{e}$ & $104(53.6)$ \\
\hline Complications $^{\mathbf{c}}$ & $115(58.7)$ \\
\hline Heart disease & $34(17.3)$ \\
\hline Eye problems & $52(26.5)$ \\
\hline Foot discomfort & $81(41.3)$ \\
\hline Foot ulcers & $14(7.1)$ \\
\hline Kidney problems & $16(8.2)$ \\
\hline
\end{tabular}

aSome missing responses

${ }^{\mathrm{b}} \mathrm{BMI}$, body mass index = weight $(\mathrm{kg})$ divided by height ${ }^{2}\left(\mathrm{~m}^{2}\right)$; some missing responses

'Respondents responded 'yes' for at least one complication/risk factor

'Respondents responded 'yes', either for "Do you have high cholesterol?" or "Do you take medications to treat your high cholesterol?", or for both

'Respondents responded 'yes', either for "Do you have high blood pressure?" or "Do you take medications to treat your high blood pressure?", or for both 


\section{Table 4(on next page)}

monitoring profile 
1 Table 4 Self-reported monitoring profile of patient respondents $(\mathrm{N}=195)^{\mathrm{a}}$

2

\begin{tabular}{lc}
\hline Patient monitoring & Frequency (\%) of 'yes' \\
\hline Diabetes (glycaemic) control & $56(28.7)$ \\
$\begin{array}{l}\text { High blood sugar reactions } \\
\text { (in the last month) }\end{array}$ & \\
$\begin{array}{l}\text { Low blood sugar reactions } \\
\text { (in the last month) }\end{array}$ & $43(22.1)$ \\
Severe blood sugar reactions \\
(in the last year)
\end{tabular}

\section{Routine tests}

$S M B G$

(in the last week)

Medical monitoring

(in the last 3 months)

Blood sugar

$167(86.1)$

Blood pressure

$166(85.1)$

Weight

HbAlc measurement

(in the last year)

Medical monitoring

(in the last year)

Cholesterol

$127(65.1)$

Kidney

Eyes

Feet

$41(21.0)$

Abbreviations: SMBG, self-monitoring of blood glucose; HbA1c, glycosylated haemoglobin

a1 missing response

${ }^{b}$ number of respondents reported their $\mathrm{HbAl} \mathrm{c}$ last value 


\section{Table 5 (on next page)}

patients' use of and views on pharmacy services 
1 Table 5 Patients' use of community pharmacy services and their views on pharmacists' roles $2(\mathrm{~N}=196)$

\begin{tabular}{|c|c|c|}
\hline Services & $\begin{array}{l}\text { Being used } \\
\mathrm{N}(\%)\end{array}$ & $\begin{array}{c}\text { Being viewed as } \\
\text { pharmacist roles }^{\mathrm{a}} \\
\mathrm{N}(\%)\end{array}$ \\
\hline \multicolumn{3}{|l|}{ Treatment administration } \\
\hline Prepare medications & $196(100)$ & $195(100)$ \\
\hline Provide labels with instructions for use & $196(100)$ & $195(100)$ \\
\hline \multicolumn{3}{|l|}{ Patient education } \\
\hline Disease process & $93(47.4)$ & $120(61.5)$ \\
\hline Treatment targets & $79(40.3)$ & $115(59.0)$ \\
\hline \multicolumn{3}{|l|}{ Antidiabetic medications: } \\
\hline Directions for use & $156(79.6)$ & $160(82.1)$ \\
\hline Use of insulin devices ${ }^{b}$ & $27(61.4)$ & $142(72.7)$ \\
\hline Storage requirements & $93(47.4)$ & $144(73.9)$ \\
\hline Special precautions to follow & $141(71.9)$ & $155(79.5)$ \\
\hline Common/important adverse effects & $87(44.4)$ & $139(71.3)$ \\
\hline Exercise & $66(33.7)$ & $96(49.2)$ \\
\hline Diet & $84(42.9)$ & $101(51.8)$ \\
\hline SMBG & $63(32.1)$ & $107(54.9)$ \\
\hline Prevention/treatment of acute complications & $67(34.2)$ & $126(64.6)$ \\
\hline Prevention/treatment of chronic complications & $45(23.0)$ & $116(59.5)$ \\
\hline Need for regular medical monitoring & $48(24.5)$ & $97(49.8)$ \\
\hline Foot self-care & $35(17.9)$ & $95(48.7)$ \\
\hline Smoking cessation ${ }^{c}$ & $12(29.3)$ & $72(36.7)$ \\
\hline \multicolumn{3}{|l|}{ Monitoring } \\
\hline \multicolumn{3}{|l|}{ Monitor compliance with: } \\
\hline Antidiabetic medications & $100(51.0)$ & $127(65.1)$ \\
\hline Exercise plan & $62(31.6)$ & $102(52.3)$ \\
\hline Diet plan & $78(39.8)$ & $109(55.9)$ \\
\hline $\begin{array}{l}\text { Plan for prevention/treatment of chronic } \\
\text { complications }\end{array}$ & $44(22.4)$ & $92(47.2)$ \\
\hline Scheduled medical monitoring & $38(19.4)$ & $96(49.3)$ \\
\hline \multicolumn{3}{|l|}{ Monitor treatment outcomes: } \\
\hline Check records on SMBG & $58(29.6)$ & $101(51.8)$ \\
\hline Carry out blood glucose tests & $58(29.6)$ & $113(58.0)$ \\
\hline Measure BMI & $40(20.4)$ & $89(45.6)$ \\
\hline Measure blood pressure & $55(28.1)$ & $103(52.8)$ \\
\hline Check results on patient laboratory tests & $51(26.0)$ & $98(50.3)$ \\
\hline Monitor for adverse effects & $63(32.1)$ & $110(56.4)$ \\
\hline
\end{tabular}


3 Abbreviations: SMBG, self-monitoring of blood glucose; BMI, body mass index

$4 \quad{ }^{\mathrm{a}} 1$ missing response

5 'The percentage was calculated for patients currently/previously taking insulin ( $\mathrm{N}=44)$

6 'The percentage was calculated for patients currently (or had a history of) smoking ( $\mathrm{N}=41$ ) 


\section{Table 6(on next page)}

Patients' open ended views on priority roles of pharmacists

Table 6 Patients' open-ended views on priority roles of pharmacists in diabetes care $(\mathrm{N}=169)^{\mathrm{a}}$ 
1 Table 6 Patients' open-ended views on priority roles of pharmacists in diabetes care $(\mathrm{N}=169)^{\mathrm{a}}$

2

\begin{tabular}{lc}
\hline Priority services $^{\mathrm{b}}$ & Number of responses (\%) \\
\hline Treatment administration & \\
\hline Prepare medications & $35(20.7)$ \\
Provide labels with instructions for use & $66(39.1)$ \\
\hline Patient education & $27(16.0)$ \\
\hline Disease process & \\
Antidiabetic medications: & $109(64.5)$ \\
$\quad$ Directions for use & $15(8.9)$ \\
$\quad$ Use of insulin devices & $45(26.6)$ \\
$\quad$ Storage requirements & $37(18.9)$ \\
$\quad$ Special precautions to follow & $50(25.5)$ \\
$\quad$ Common/important adverse effects & $27(13.8)$ \\
Exercise & $33(16.8)$ \\
Diet & $27(16.0)$ \\
Prevention/treatment of acute complications & $20(11.8)$ \\
Prevention/treatment of chronic complications & \\
\hline Monitoring & \\
\hline
\end{tabular}

Monitor compliance with:

Antidiabetic medications

Monitor treatment outcomes:

Carry out blood glucose tests

Measure blood pressure

Monitor for adverse effects

Others (not a specific service)

Provide a complete range of medications

$12(7.1)$

Information about medications

$16(9.5)$ 3 Responses to an open-ended question: "In your opinion, what are the five most important services that should be provided at pharmacies to assist
4 you with your diabetes?"

${ }^{a}$ From a total 196 respondents, there were 26 missing responses and 1 invalid response, giving a total $\mathrm{N}=169$

bServices selected by more than 10 respondents 
Table 7 (on next page)

significant characteristics associated with support for 'patient education' and 'monitoring' by pharmacists 
1 Table 7 Odds ratios and 95\% confidence intervals of significant characteristics associated with support for 'patient education' and

2 'monitoring' by pharmacists

\begin{tabular}{|c|c|c|c|c|c|c|c|c|c|}
\hline & \multirow{3}{*}{$\mathbf{N}$} & \multicolumn{4}{|c|}{ Patient education by pharmacists } & \multicolumn{4}{|c|}{ Monitoring by pharmacists } \\
\hline & & \multirow[t]{2}{*}{ Medications $^{\mathrm{a}}$} & \multirow[t]{2}{*}{ Exercise } & \multirow[t]{2}{*}{ Diet } & \multirow[t]{2}{*}{ All education ${ }^{\mathrm{b}}$} & \multirow[t]{2}{*}{ Compliance } & \multicolumn{2}{|c|}{ Treatment outcomes } & \multirow{2}{*}{$\begin{array}{l}\text { Adverse drug } \\
\text { reaction }\end{array}$} \\
\hline & & & & & & & $\begin{array}{c}\text { Perform clinical } \\
\text { testings }^{\mathrm{d}}\end{array}$ & $\begin{array}{c}\text { Check test } \\
\text { results }\end{array}$ & \\
\hline \multicolumn{10}{|l|}{ Income } \\
\hline Low & 105 & reference & reference & reference & reference & reference & & & reference \\
\hline Moderate & 54 & NS & $0.4(0.17-0.90)$ & NS & NS & NS & & & NS \\
\hline High & 37 & $0.3(0.10-0.72)$ & $0.3(0.10-0.80)$ & $0.3(0.12-0.61)$ & $0.3(0.10-0.68)$ & $0.3(0.10-0.72)$ & & & $0.2(0.09-0.53)$ \\
\hline \multicolumn{10}{|l|}{ Employment } \\
\hline Not working & 123 & & reference & & reference & reference & reference & reference & \\
\hline Working & 73 & & $0.3(0.15-0.83)$ & & $0.5(0.24-0.94)$ & $0.4(0.21-0.88)$ & $0.5(0.24-0.97)$ & $0.3(0.15-0.74)$ & \\
\hline \multicolumn{10}{|l|}{ Risk factors } \\
\hline No & 39 & & & & & & & & reference \\
\hline Yes & 157 & & & & & & & & $3.4(1.46-8.03)$ \\
\hline \multicolumn{10}{|c|}{$\begin{array}{l}\text { Diabetes (glycaemic) } \\
\text { control }^{\mathrm{f}}\end{array}$} \\
\hline Good/fair & 23 & & & & & & reference & reference & reference \\
\hline Poor & 90 & & & & & & NS & $4.9(1.20-20.55)$ & $3.2(1.05-9.97)$ \\
\hline Unknown & 83 & & & & & & $2.3(1.22-4.51)$ & $10.2(2.44-42.95)$ & $4.3(1.36-13.57)$ \\
\hline \multicolumn{10}{|c|}{ Previous use of the service } \\
\hline No & $\mathrm{g}$ & reference & reference & reference & reference & reference & reference & reference & reference \\
\hline Yes & & $4.5(1.79-11.53)$ & $10.3(4.6-23.15)$ & $4.4(2.30-8.30)$ & $4.5(1.60-12.51)$ & $5.2(1.79-11.52)$ & $13.6(5.21-35.51)$ & $11.3(4.51-28.13)$ & $6.3(2.82-13.90$ \\
\hline
\end{tabular}

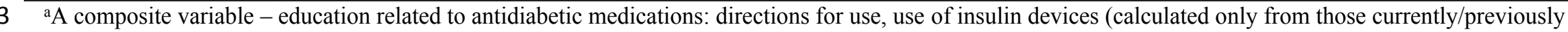

4 taking insulin), storage, special precautions and common/important adverse effects; a mean rating $\geq 5$ was used

5 bA composite variable - all education: disease process, treatment targets, antidiabetic medications, exercise, diet, self-monitoring of blood glucose,

6 prevention/treatment of acute complications, prevention/treatment of chronic complications, need for regular monitoring, foot self-care and smoking cessation

(calculated only from those currently, or had a history of, smoking); a mean rating $\geq 5$ was used

$8{ }^{\mathrm{c}} \mathrm{A}$ composite variable - monitoring compliance with: antidiabetic medications, exercise and diet plan, plan for prevention/treatment of complications and

scheduled medical monitoring; a mean rating $\geq 5$ was used

${ }^{\mathrm{d}} \mathrm{A}$ composite variable - perform clinical testings (measuring blood glucose, blood pressure and BMI); a mean rating $\geq 5$ was used

eA composite variable - check test results (patient self-monitoring records and laboratory data); a mean rating $\geq 5$ was used

fDiabetes (glycaemic) control is a composite variable of hyper/hypoglycaemia symptoms and HbAlc values

$\mathrm{NS}=$ not significantly different from the reference

g Numbers differ for each endpoint (service) 